\title{
Unemployment as Factor of International Migration
}

\author{
Eleonora Matouskova \\ Ekonomická univerzita v Bratislave, Slovakia
}

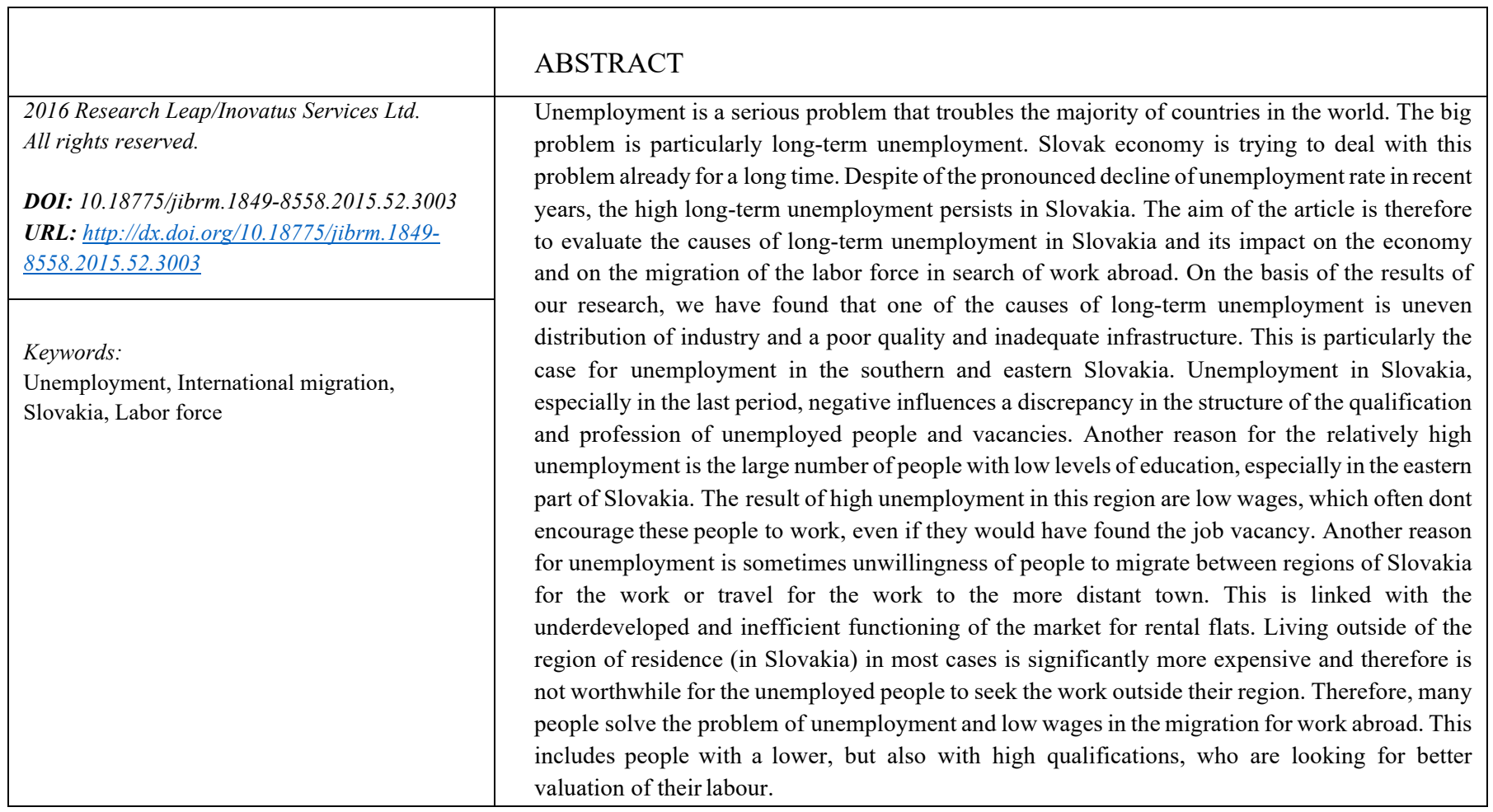

\section{Introduction}

Unemployment is one of the most serious problems that plague the current society. The Constitution of the Slovak Republic regulates the social rights of citizens in the form of the right to work and at the same time in the form of contributions of citizens, who not from their ownguilt do not work. Jandourek (2012, p. 169) defines unemployment as a state, where people are looking for work, because they want to work, the work is a source of livelihood of them, but they cannot find any reasonable and paid work. The phenomenon of unemployment is examined in a number of scientific disciplines, for example, in economics, psychology, or social policy. From the perspective of economic theory there are two dimensions of unemployment microeconomic and macroeconomic. From a microeconomic perspective, unemployment affects not only the individual, who lost a job, thereby limits his revenue, but it also means the overall reduction in the standard of living for the whole family. Unemployed people have the material, but also the social problems. Macroeconomic dimension of unemployment is related to the essence of the functioning of the economy as a whole, question of the use of available resources and loss of creation of GDP in the case of higher levels of unemployment. Unemployment increases deficit of the state budget, and this in two ways. One way are the losses in the tax area, which reduces the revenues of the state budget. The second way are the expenditures connected with the payment of the unemployment benefits and social benefits, which increases the expenditure page of the state budget.

The big problem is particularly long-term unemployment. Slovak economy is trying to deal with this problem already for a long time. The aim of the article is therefore to evaluate the causes of long-term unemployment in Slovakia and its impact on the economy and on the migration of the labour forces.

\section{Development of Unemployment in Slovakia and in European Union}

During the period of high economic growth $(2004-2008)$ the total unemployment in Slovakia decreased. The unemployment rate declined approximately from $18 \%$ in 2004 to $8,7 \%$ in 2008 . 
This positive trend stopped the financial and economic crisis. Unemployment rate started again to increase and later stagnated around 14\% (2010-2013). This has not prevented the recovery of the economy and economic growth, which, however, was significantly lower than in the pre-crisis period. From 2014, the unemployment rate in Slovakia has begun gradually to reduce. In the spring 2015, registered unemployment decreased to $12,06 \%$ and in 2016 to $9,9 \%$.

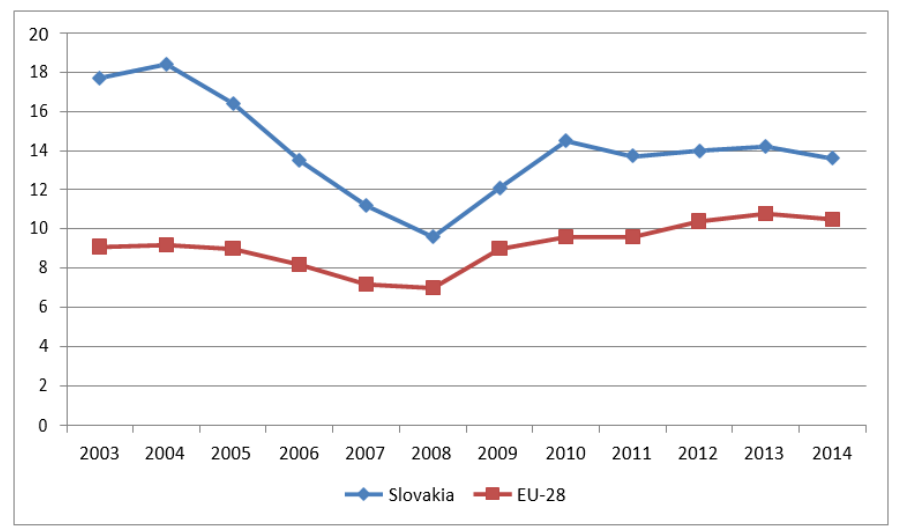

Figure 1: Unemployment rate in Slovak Republic and in EU28 (processed on the basis of Eurostat data)

Unemployment in Slovakia reaches in the longterm higher values than the average EU countries. The economic cycle is manifested also in the fluctuation of unemployment rate, so in Slovakia, as well as in the EU countries. In both economies can be find the pre-crisis decrease of the unemployment rate, then its growth during the global crisis coupled with the decline of real GDP and later, after a brief recovery, stagnation around the level $14 \%$ in Slovakia and $11 \%$ in EU.

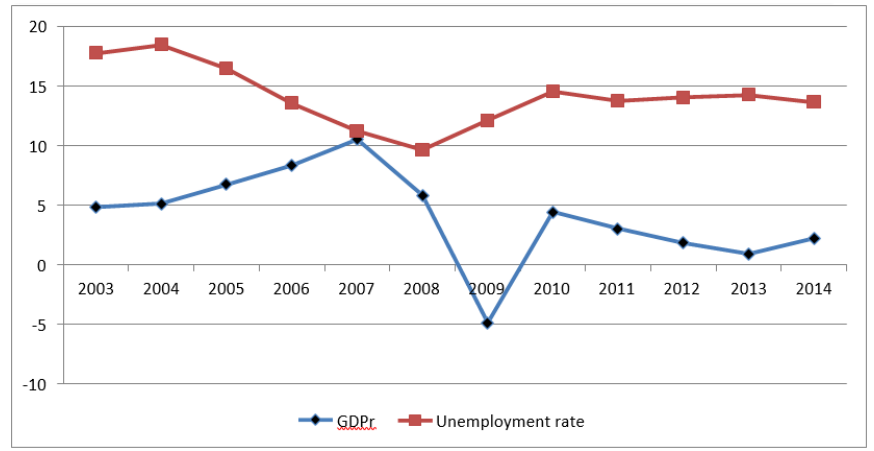

Figure 2: Development of real GDP and unemployment rate in Slovak Republic; annual rate of change in \% (processed on the basis of Eurostat data)

The highest unemployment rate within the countries of Visegrad four (V4 countries) at the beginning of the reporting period, i. e. in 2003, amounted to Poland (almost $20 \%$ ), followed by Slovakia (about $18 \%$ ). Unemployment rate in this period was significantly lower in Czech republic (7,5\%) and in Hungary (6 $\%)$. In the pre-crisis period, which was characteristic with high economic growth, the unemployment rate in Poland and in Slovakia significantly has been reduced and in 2008 decreased to $9,6 \%$ (Slovakia) and 7,5\% (Poland). This positive trend was stopped in the time of global financial crisis and economic recession.
At the time of second, more modest economic recession in 2012 , the unemployment rate in the EU, as well as in Slovakia rose slightly. Similar increase in unemployment was recorded again in 2013. The unemployment rate reached $14 \%$ in Slovakia. Until the end of 2013, the number of unemployed people decreased. The unemployment rate in the EU, however, in post-crisis period (2013) remained at a relatively high level (10,8 \% EU, respectively $12 \%$ euro area), despite the economic recovery in the EU. Stabilization on the labour market occurred in 2014, when the unemployment rate began slightly to decrease (in the EU to $10,3 \%$ and in the euro area to $11,8 \%$ ). In the first half of the year 2015 fell in Slovakia to 12,06 \%. It can be expected that in the coming years as a result of the continuing trend of a decline in unemployment and growth of real incomes of consumers will increase the final consumption of households, and therefore also total domestic demand. The engine of economic growth after a long time so should become domestic demand (Morvay, 2015, p. 61).

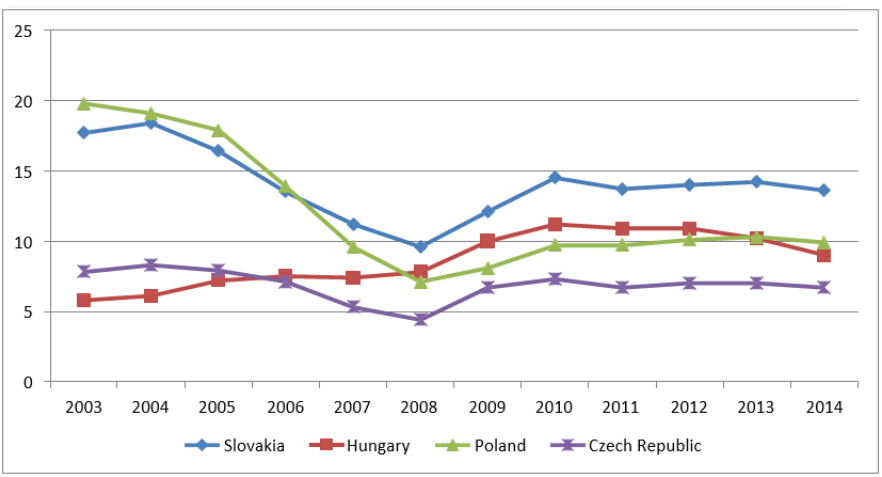

Figure 3: Development of unemployment in the V4 countries; annual change of rate in \% (processed on the basis of Eurostat data)

\section{The Causes of Unemployment in Slovakia and Labour Migration}

Slovak labour market reached the highest number of jobs in 2016 and the unemployment rate fell for the first time below the average of the euro area. Development in the labour market, however, is significantly affected by demographic development. In the next few years, a large proportion of the labour force will vanish in Slovakia. In the half year 2016, the number of Slovak workers has increased on 2490000 . It is about 86000 workers more than in the same quarter of 2008 , which has been the most successful year for the Slovak labour market. The unemployment rate has fallen below $10 \%$ in 2016 , for the first time below the euro area average. This year, however, will not fall to the historic low $(8,7 \%)$ from the end of 2008 , because the rate of economic activity of the Slovaks has risen. Although the number of people in the working age has lowered, interest in the work of those who have remained grew. The number of economically active population so, overall, increased. Demographic profile of the population of Slovakia is going through significant changes. In 10 years there will be about 130000 pensioners $(64+)$, on the contrary, from young graduates (23 - 30 years) will wane approximately 120 000. Economically active people will wane, decrease in the unemployment rate so will speed up even without creation of new jobs. Demographic development will cut the unemployment rate in 2017 by $2-3$ tenths of a percentage point 
$(0,2-0,3 \%)$, in 2018 by another $3-4$ tenths $(0,3-0,4 \%)$, in 2019 about 5 tenths $(0,5 \%)$. In the next decade it will be cumulative by a few percentage points. The number of unemployed in Slovakia, 265000 people, is still high, on the labour market is, however, an inconsistency in the structure of demand and supply of labour. More than $50 \%$ of the unemployed have only basic education or apprenticeship without leaving examination. But the labour market shows that only one of the three or four posts (jobs) are suitable for such jobseekers. Also many people were long out of work and have lost their qualification. More than half of the unemployed (58\%) are out of work more than one year, one quarter of the unemployed did not work even more than four years. Tens of thousands of Slovaks are working abroad. Their return could increase the supply of skilled labour.

Trend is, however, quite the opposite. Labour migration abroad is growing. About 165000 Slovaks commute for work abroad, especially to Austria, Germany and the Czech Republic. The strongest migration flow to the Czech labor market comes from the Slovak Republic. After 1993, the number of Slovak workers in the Czech Republic grew rapidly and their share on the foreign labor force reached almost $40 \%$. Reasons for such a development are related to the geographical location, cultural and linguistic proximity, and advantageous legislative conditions for the employment of Slovaks. The popularity of Czech job positions in the other 5 years is declining in favour of Austria and Germany (Rievajová - Př̀viara, 2013, p. 66). The number of people working abroad is growing year on year faster than the number of jobs at home. The share of Slovaks who commute to work abroad on the total number of workers has increased from $4,9 \%$ at the beginning of 2012 on the current 6,6 $\%$. High long-term unemployment in Slovakia has a number of reasons. To the most common and most important causes of unemployment may include lack of education and skills of the long-term unemployed persons. Another reason is the reluctance of people to migrate in search of work or to commute to another city. In Slovakia is this problem associated with inefficient functioning of the market of rental housing, therefore a job outside of the region of residence of the candidate on the job is a problem. Living outside the region of residence of unemployed person may be significantly more expensive, or is characterized by lack of capacity. Factor that discourages potential jobseekers are high social contributions in Slovakia. For every euro that the employee earned in net wages, falls 56 cents, that have been paid to the Social insurance agency (Dinga - Durana, 2015, p. 8 - 10). This overcharge in prices work reduces the willingness of unemployed people to work. A similar problem also represents the amount of the minimum wage, which is one of the deciding factors, whereas wage as the price of the work is a main motivation of the people to work. It is necessary to look at the amount of the minimum wage from two perspectives - from the perspective of an employer, that examines whether a potential employee will bring him at least the value of the minimum costs incurrred to him and also from the perspective of the employee who will be willing to work for such a sum. Other reasons of long- term unemployment are also various barriers of psychological nature, income from work on black, the passivity of the people, an unwillingness to cooperate with the Labour office. Slovakia achieved the second highest rates of long-term unemployment in the EU. The Slovak labour market cannot deal in particular with two groups of unemployed people - young people (graduates) and persons with low levels of education. A significant problem with the integration in the labour market has another group of citizens - ethnic groups. A forecast of the development of the Roma population say, that from the current 400000 persons other 300000 Roma in the coming years will get into the labour market. In view of the very high unemployment of this ethnicity, especially the long-term, the Slovak economy may not handle this situation, if will be not used appropriate and efective measures. The long-term unemployment in Slovakia is concentrated. The highest is in the southern districts of Central Slovakia and in Eastern Slovakia. Highest unemployment rate of all counties in Slovakia amounts to Preńovský kraj (county). Its surface area is the second largest in Slovakia. Is located in the east of Slovakia and borders with Poland and Ukraine. In this region is a higher representation of people with low levels of education, for example apprenticeship without a leaving examination. Problems are therefore also the low wages - they are achieving the lowest level in Slovakia. The average monthly wage in 2013 here reached a level of 586 EUR, while the national level was 789 EUR. This county suffers from long-term unemployment a long time, already in 2001 the unemployment rate has reached a level of $23,59 \%$. The consequence of such situation is the fact that the long-term unemployed tend to be out of job and do not attempt to get a work. They learn how to use the social benefits, or unemployment benefits and lose their qualification. Companies then even if they need the workers, refuse to employ the longterm unemployed who have lost skill and a willingness to be given the highest performance. The consequence is a reduction in the performance of the economy, lower growth of GDP compared to making full use of resources (labor forces). As a result of high unemployment is a migration for work and a high proportion of the labour forces working abroad.

\section{Conclusion}

Unemployment (in particular, the long-term) is the most serious macroeconomic problem in Slovakia. Is the subject of a major cyclical fluctuations. Of the approximately $18 \%$ in 2003 , thanks to the high rates of economic growth had fallen to $8,7 \%$ in 2008 . The favourable development of the economy has been undermined by the global financial and economic crisis, which mainly due to a decline in foreign demand was fully demonstrated also in the Slovak economy. Unemployment then has increased to $14 \%$. In the post-crisis period, gradually managed to start up economic growth and unemployment fell again. Currently reaches approximately 9,9\%. However, the number of people working abroad has been sustained. Despite of new foreign investment to Slovakia and the creation of new 
jobs, the number of people interested in working abroad is not declining. This is due to the relatively low wages in Slovakia in comparison with the level of wages in many EU countries, what motivates people to look for work abroad. Another reason is the regional imbalance in investments in Slovakia, which are directed primarily to the more developed regions of Slovakia (especially western Slovakia) and just the less developed areas of Slovakia are circumventing. The cause of this can be found also in the lack of infrastructure in less developed areas and in the lower level of the qualification of unemployed people in these regions.

\section{References}

- Dinga, J., Ďurana, R. (2015). Nezamestnanost' - systémový problém slovenského hospodárstva. Bratislava: INESS.

- Jandourek, J. (2012). Slovnik sociologických pojmu. Praha: Grada Publishing.

- Matouńková, E. (2015). Hospodársky cyklus. Bratislava: Ekonñm.

- Morvay, K. a kol. (2015). Hospodársky vývoj Slovenska v roku 2014 a výhl'ad do roku 2016. Bratislava: EÚ SAV.

- Pribúda penzistov, ubúda absolventov. Bude mat' kto pracovat? Pravda. Retrieved 28.10.2016 from http://www.profesia.sk/ludske=zdroje/clanok/409315 pribuda-penzistov-ubuda-absolventov-bude-mat-ktopracovat/

- Rievajová, E., Př̀vara, A. (2013). International labor migration in the Slovak Republic and Czech Republic after accession to the European Union. In The New Economy (p. 62-69). Bratislava: EU v Bratislave.

- Eures. Preńovský kraj. (2016). Retrieved 23.04.2016 from http://ec.europa.eu/eures/main.jsp?countryId=SK\&acro=lmi $\&$ showRegion $=$ true\&lang $=$ sk\&mode $=$ text\&regionId $=$ SK0 \&nuts 2 Code $=$ SK02\&nuts 3 Code $=$ SK021\&catId $=2811>$ 